\title{
Re-evaluation of Cryptosporiopsis eucalypti and Cryptosporiopsis-like species occurring on Eucalyptus leaves
}

\author{
R. Cheewangkoon • J. Z. Groenewald • G. J. M. Verkley • K. D. Hyde • \\ M. J. Wingfield • M. Gryzenhout • B. A. Summerell • S. Denman • C. Toanun • \\ P. W. Crous
}

Received: 9 March 2010 / Accepted: 8 April 2010 /Published online: 30 April 2010

(C) The Author(s) 2010. This article is published with open access at Springerlink.com

\begin{abstract}
Cryptosporiopsis eucalypti is a common follicolous pathogen of Eucalyptus species in tropical and temperate regions where these trees are grown in plantations. The taxonomy of $C$. eucalypti is confused by the fact that it is phylogenetically unrelated to the type species of Cryptosporiopsis (Cryptosporiopsis nigra $=$ C. scutellata, Helotiales). The aim of this study was to resolve the
\end{abstract}

R. Cheewangkoon $\cdot$ C. Toanun

Department of Plant Pathology, Faculty of Agriculture,

Chaing Mai University,

Chaing Mai 50200, Thailand

J. Z. Groenewald · G. J. M. Verkley • P. W. Crous $(\square)$

CBS-KNAW Fungal Biodiversity Centre,

Uppsalalaan 8,

3584 CT Utrecht, The Netherlands

e-mail: p.crous@cbs.knaw.nl

K. D. Hyde

School of Science, Mae Fah Luang University,

Chiang Rai 57100, Thailand

K. D. Hyde

Botany and Microbiology Department, College of Science,

King Saud University,

Riyadh, Saudi Arabia

M. J. Wingfield • M. Gryzenhout

Forestry and Agricultural Biotechnology Institute (FABI),

University of Pretoria,

Pretoria 0002, South Africa

B. A. Summerell

Royal Botanic Gardens and Domain Trust,

Mrs. Macquaries Road,

Sydney NSW 2000, Australia

S. Denman

Forest Research, Alice Holt Lodge,

Farnham, Surrey GU10 4LH, UK taxonomic position of C. eucalypti based on morphology and phylogenetic inference. Thirty-two Eucalyptus leaf samples with symptoms typical of $C$. eucalypti infection were collected from 10 tropical and temperate countries across four continents. Cultures were established from single conidia, as well as from ascospores of a previously unreported teleomorph state. DNA sequences were obtained for the $28 \mathrm{~S}$ nrDNA, the internal transcribed spacers of the nrDNA operon, and beta-tubulin regions to determine generic and species-level relationships. DNAsequence analysis showed that conidial and ascospore isolates of $C$. eucalypti have low intraspecific variation, although two collections from Australia and one from Uruguay represented two novel taxa. Based on the newly collected teleomorph stage, as well as the phylogenetic data, C. eucalypti is shown to represent a new genus closely related to Plagiostoma (Gnomoniaceae, Diaporthales) for which the names Pseudoplagiostoma gen. nov. and Pseudoplagiostomaceae fam. nov. (Diaporthales) are introduced. Two new species of Cryptosporiopsis (Dermateaceae, Helotiales) on Eucalyptus from Australia and California (USA) are also described.

Keywords Cryptosporiopsis eucalypti - Diaporthales . DNA phylogeny $\cdot$ Eucalyptus $\cdot$ Pseudoplagiostoma

\section{Introduction}

Cryptosporiopsis eucalypti is a host-specific pathogen of Eucalyptus species that occurs over a wide geographical range varying from dry to very humid zones including those in Australia, India, Hawaii (Sankaran et al. 1995), New Zealand (Gadgil and Dick 1999), Brazil (Ferreira et al. 
1998), Japan, Laos, Indonesia, Sri Lanka, Thailand and Vietnam (Old and Yuan 1994; Old et al. 2003). The fungus can be associated with various disease symptoms including leaf spots, shoot blight, cankers on woody tissue, defoliation and even tree death.

The leaf spots develop on both sides of leaves and vary in size, shape, and colour among Eucalyptus species (Sharma 1994; Sankaran et al. 1995; Old et al. 2002, 2003). The fungus proliferates by producing a vast number of spores from conidiomata that develop on infected leaves and shoots. After causing death of shoot tips or small branches, repeated infection can occur over extended periods of time. Leaf blight and other foliar diseases induced by $C$. eucalypti can easily be confused with those caused by other plant-pathogenic fungi, such as Mycosphaerella spp. and their anamorphs (Cheewangkoon et al. 2008, 2009; Crous 2009), and Calonectria (Crous et al. 2004b, 2006a; Lombard et al. 2009, 2010).

Although infection by $C$. eucalypti can eventually lead to yield reduction of Eucalyptus plantations, the biology of this pathogen is not well understood. Infection often appears to be associated with minor mechanical, insect or wind damage (Ciesla et al. 1996), or with lesions caused primarily by Calonectria spp. (Park et al. 2000; Crous 2002). Old and Yuan (1999) also reported the cooccurrence of $C$. eucalypti with Pilidiella species (as Coniella; Van Niekerk et al. 2004) on E. camaldulensis, showing serious defoliation in the North Queensland region of Australia. Cryptosporiopsis foliar disease develops under conditions of high humidity, and the optimum temperature for its growth and sporulation on agar is $25-26^{\circ} \mathrm{C}$, while temperatures of $32^{\circ} \mathrm{C}$ or above appear to limit disease development. In contrast, low ambient temperatures may be a predisposing factor for initiation of disease (Sankaran et al. 1995). Spread of C. eucalypti is probably through wind and rain splash dissemination, and it is unknown whether the fungus can be spread via contaminated seed or chaff commonly found in seed lots (Ciesla et al. 1996).

Cryptosporiopsis eucalypti was first described by Sankaran et al. (1995). Verkley (1999) suggested that it differs from typical Cryptosporiopsis anamorphs by only having acervuloid conidiomata with discrete conidiogenous cells, lacking any stromatic tissue in culture. In contrast many species of Cryptosporiopsis s. str. as typified by $C$. scutellata (syn. C. nigra), anamorph of Pezicula ocellata, form integrated conidiogenous cells on conidiophores, and in culture, are always associated with stromatic tissue.

Cryptosporiopsis eucalypti was nonetheless accepted in Cryptosporiopsis by Verkley (1999) based on its morphological characteristics. Species of Cryptosporiopsis have known teleomorphs in Pezicula and Neofabraea (Dermateaceae, Helotiales; Sutton 1980; Verkley 1999), though presently no teleomorph has yet been linked to C. eucalypti.
During routine surveys of Eucalyptus leaf diseases, an unknown ascomatal fungus was found associated with leaf spots resembling those caused by $C$. eucalypti. Because single ascospore isolates produced typical C. eucalypti colonies in culture, these strains were included in a phylogenetic study pursuing the hypothesis that it might represent the teleomorph of $C$. eucalypti. Furthermore, based on preliminary phylogenetic data for $C$. eucalypti and similar fungi, we concluded that these taxa could not be accommodated in the Dermateaceae (Helotiales), but rather that they represented a novel clade in the Diaporthales (unpubl. data).

The aim of this study was to consider the phylogenetic relationships among C. eucalypti-like fungi collected from Eucalyptus leaves and twigs in many parts of the world. This was achieved by employing sequences of the internal transcribed spacer (ITS) sequences of the nuclear ribosomal DNA operon (ITS1, 5.8 S nrDNA and ITS2) and the Btubulin (TUB) gene. Furthermore, to resolve their higher order phylogeny, sequences were generated from the 28 nrRNA (LSU) gene. For morphological comparisons, isolates were studied on a range of culture media and growth conditions.

\section{Materials and methods}

\section{Isolates}

Lesions bearing ascomata were cut from Eucalyptus leaves, soaked in distilled water for $2 \mathrm{~h}$, and then attached to the inside lower surfaces of Petri dish lids, with the top halves of dishes containing 2\% malt extract agar (MEA; Oxoid, Hampshire, England). Germinating ascospores on the agar surface were examined after $24 \mathrm{~h}$, and single ascospore cultures were established as described earlier (Crous et al. 1991; Crous 1998).

Eucalyptus leaves were incubated in moist chambers for up to $2 \mathrm{wk}$, and single conidial colonies established from sporulating conidiomata (Crous 2002). Colonies were sub-cultured onto $2 \%$ potato-dextrose agar (PDA), synthetic nutrient-poor agar (SNA), MEA, oatmeal agar (OA; Crous et al. 2009), and pine needle agar (2\% tap water agar, with sterile pine needles) (PNA; Crous et al 2006b), and incubated under continuous near-ultraviolet light at $25^{\circ} \mathrm{C}$ to promote sporulation. Nomenclatural novelties with their descriptions were recorded in MycoBank (www.MycoBank.org; Crous et al. 2004a). All cultures obtained in this study are maintained in the culture collection of the CBS-KNAW Fungal Biodiversity Centre (CBS) in Utrecht, the Netherlands, and/or the working collection (CPC) of P.W. Crous (Table 1). 
DNA isolation, amplification and phylogeny

Genomic DNA was isolated from fungal mycelium grown on MEA, using the UltraClean ${ }^{\circledR}$ Microbial DNA Isolation Kit (Mo-Bio Laboratories, Inc., Solana Beach, CA, USA) following the manufacturer's protocols. The primers V9G (de Hoog and Gerrits van den Ende 1998) and LR5 (Vilgalys and Hester 1990) were used to amplify part of the nuclear rDNA operon spanning the $3^{\prime}$ end of the $18 \mathrm{~S}$ rRNA gene (SSU), the first internal transcribed spacer (ITS1), the $5.8 \mathrm{~S}$ rRNA gene, the second ITS region (ITS2) and the first 900 bases at the $5^{\prime}$ end of the $28 \mathrm{~S}$ rRNA gene (LSU). The primers ITS4 (White et al. 1990) and LR0R (Rehner and Samuels 1994) were used as internal sequence primers to ensure good quality sequences over the entire length of the amplicon. To resolve species identities, the ITS region was supplemented with sequences of the $\beta$ tubulin gene (TUB) using the primers T1 (O'Donnell and Cigelnik 1997) and Bt-2b (Glass and Donaldson 1995). The PCR conditions, sequence alignment and subsequent phylogenetic analyses followed the methods of Crous et al. (2006a). Sequences were compared with those available in NCBI's GenBank nucleotide (nr) database using a megablast search and results are provided in the relevant species notes where applicable. Alignment gaps were treated as fifth character states. Sequence data were deposited in GenBank (Table 1) and alignments in TreeBASE (www.treebase.org).

\section{Morphology}

Isolates were plated onto fresh MEA, OA, PDA and PNA plates, and subsequently incubated at $25^{\circ} \mathrm{C}$ under nearultraviolet light to promote sporulation. Fungal structures were mounted on glass slides in clear lactic acid for microscopic examination. Sections of ascomata were made by hand for examination purposes. Measurements of all taxonomically relevant characters were made at $1,000 \times$ magnification by Nikon NIS-Elements D3.0 Imaging Software, with 50 measurements per structure where possible. Colony colours on MEA (surface and reverse) were determined using the colour charts of Rayner (1970) after $1-2$ wk at $25^{\circ} \mathrm{C}$ in the dark.

\section{Results}

Phylogenetic analysis

Approximately 1,700 bases, spanning the ITS and LSU regions, were obtained for isolates listed in Table 1. The LSU region was used in the phylogenetic analysis to determine generic or family placements and ITS sequences were used to determine species-level relationships. The LSU alignment contained 78 taxa (including the outgroup sequence) and, of the 753 characters used in the phylogenetic analysis, 214 were parsimony-informative, 53 were variable and parsimony-uninformative and 486 were constant. The first 1,000 equally most parsimonious trees were kept from the heuristic search, the first of which is shown in Fig. $1(\mathrm{TL}=784, \mathrm{CI}=0.490, \mathrm{RI}=0.883, \mathrm{RC}=0.433)$. The phylogenetic tree for the LSU region (Fig. 1) revealed the family relationships for the isolates within Diaporthales and Helotiales. Isolates that had been tentatively identified as $C$. eucalypti did not reside in any existing family, and a new genus and family is introduced below to accommodate them.

A second alignment of sequences for the C. eucalypti isolates based on ITS and TUB sequences included a combined set of 1,256 characters (incl. alignment gaps) (number of included characters: ITS: 525 and TUB: 731). Of the 32 sequences used (including the outgroup), 386 characters were parsimony-informative, 91 were variable and parsimony-uninformative, and 779 were constant. A total of 212 equally most parsimonious trees were obtained from the heuristic search, the first of which is shown in Fig. $2(\mathrm{TL}=524, \mathrm{CI}=0.987, \mathrm{RI}=0.984, \mathrm{RC}=0.971)$. Isolates originally identified as " $C$. eucalypti" were found to represent two novel species of Cryptosporiopsis, and three novel species that represented a new genus and family (Figs. 1, 2). Further results are discussed in the species notes sections below where applicable.

Morphology

Results of this study led to the discovery of two novel species of Cryptosporiopsis s.str. on Eucalyptus. Furthermore, single ascospore isolates of a diaporthalean fungus produced colonies typical of $C$. eucalypti in culture. Phylogenetic analyses of sequence data showed that this collection represents a previously undescribed genus and family, which are treated below.

Cryptosporiopsis californiae Cheewangkoon, Denman \& Crous, sp. nov. Fig. 3

MycoBank MB516493.

Etymology: Named for the state of California, USA where the fungus was collected.

Maculae amphigenae, subcirculares ad irregulares, brunneae. Conidiomata pycnidialia ad acervularia, superficialia vel pro parte immersa, brunnea ad atrobrunnea, discreta vel confluentia, $80-130 \mu \mathrm{m}$ diam, 45-70 $\mu \mathrm{m}$ alta. Conidiophora nulla vel ad 1-2 cellulis brevibus reducta sunt. Cellulae conidiogenae discretae, phialidicae, incrassatae, cylindricae, plerumque infra apice leniter inflatae, hyalinae, (4-)8-11(-16) $\times 2.5-3.5 \mu \mathrm{m}$. Conidia elongate ellipsoidea, recta vel leniter curvata, nonnulla inaequilateralia, apex 


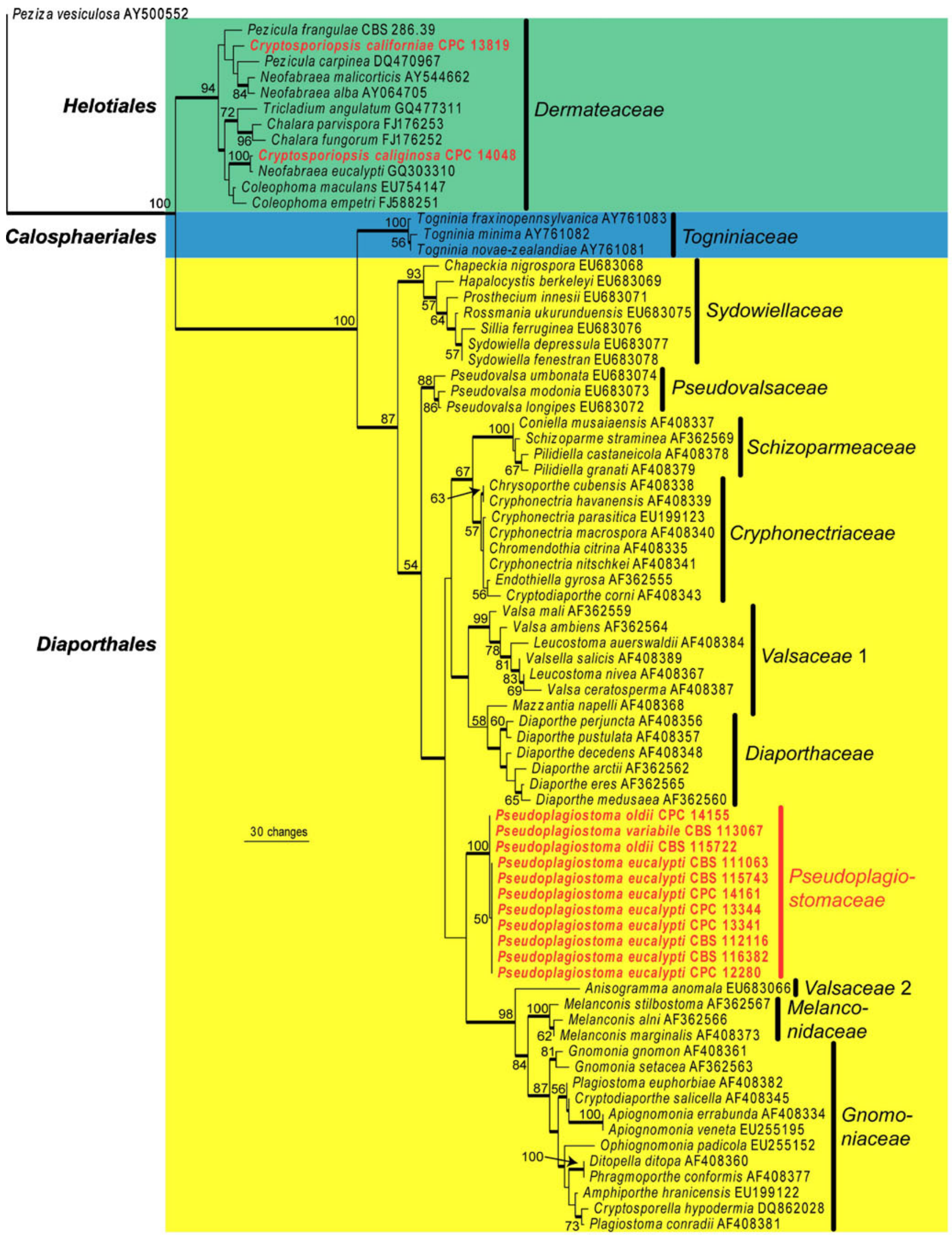


Fig. 1 The first of 1,000 equally most parsimonious trees obtained from a heuristic search with 100 random taxon additions of the LSU sequence alignment. The scale bar shows 30 changes, and bootstrap support values from 1,000 replicates are shown at the nodes. Novel species and families described in this study are shown in red. Branches present in the strict consensus tree are thickened. Orders are indicated to the left and families to the right of the tree. The tree was rooted to a sequence of Peziza vesiculosa (GenBank accession AY500552)

obtusus vel late acutus, basi abrupte angustata hilo leniter protrudente, 1.5-2 $\mu \mathrm{m}$ lato, aseptata, hyalina, crassitunicata, guttulis 5-30 minutis, $(12.5-) 15-18(-27.5) \times(4.2-) 4.5-5.2$ $(-5.8) \mu \mathrm{m}$.

Leaf spots amphigenous, subcircular to irregular, medium brown. On PNA: mycelium immersed, consisting of branched, hyaline to very pale brown, $2.5-3.5 \mu \mathrm{m}$ wide hyphae. Conidiomata pycnidial to acervular, superficial or partly immersed, medium to dark brown, with cream conidial masses; separate or confluent, 80-130 $\mu \mathrm{m}$ diam, 45-70 $\mu \mathrm{m}$ high; wall dark brown, pseudoparenchymatous, thick, composed of irregular, medium brown cells that become pale brown towards the inner region, 8-15 $\mu \mathrm{m}$ thick; stroma weakly developed, 5-10 $\mu \mathrm{m}$ thick, paler in non-pycnidial conidiomata, consisting of numerous sterile hyphae. Conidiophores absent, or reduced to 1-2 short supporting cells. Conidiogenous cells arise from the inner cells of the cavity, discrete, phialidic, thickened, cylindrical, mostly slightly enlarged below the apex, hyaline, (4-)8-11 $(-16) \times 2.5-3.5 \mu \mathrm{m}$. Conidia elongate ellipsoidal, straight or slightly curved, some inaequilateral, apex obtuse or broadly acute, tapering abruptly to a slightly protruding scar at the base, 1.5-2 $\mu \mathrm{m}$ wide; aseptate, hyaline, thick-walled, with 5-30 min guttules per conidium, (12.5-)15-18(-27.5) $\times$ (4.2-)4.5-5.2(-5.8) $\mu \mathrm{m}$.

Culture characteristics: Colonies reaching $4 \mathrm{~cm}$ diam on MEA after $1 \mathrm{wk}$ at $25^{\circ} \mathrm{C}$, slightly raised, olivaceous-grey to buff (surface), with white margin, and dense white aerial mycelium; yellow-brown (reverse). Numerous black pycni dia are produced on the colony surface that is partly submerged, irregular.

Specimen examined: USA, California, on Eucalyptus sp., Mar. 2009, S. Denman, holotype CBS H-20302, culture ex-type CPC 13819=CBS 124819, CPC 13820, 13821.

Notes: Numerous pycnidia are formed on OA after about $3 \mathrm{wk}$, which become fertile after 5 wk. Conidia are mostly similar in shape and size to those formed on PNA, but slightly shorter. Based on conidial size, $C$. californiae $(12.5-27.5 \times 4.2-5.8 \mu \mathrm{m})$ is easily distinguished from $C$. edgertonii $(30-48 \times 12-15 \mu \mathrm{m})$, which also occurs on Eucalyptus (Edgerton 1908). Although $C$. californiae may occur on other hosts, we were unable to locate a name for it, and BLAST results for its ITS sequences did not reveal its presence in GenBank. The ITS sequence of this species had an E-value of 0.0 with the ITS sequences of Pezicula spp. and Cryptosporiopsis spp. such as $P$. carpinea (AF141197; $95 \%$ identical), $P$. heterochroma (AF141167; $95 \%$ identical), P. sporulosa (AF141172; 94 \% identical), C. radicicola (AF141193; 95 $\%$ identical), C. melanigena (AF141196; $94 \%$ identical) and others.

Cryptosporiopsis caliginosa Cheewangkoon, Summerell \& Crous, sp. nov. Fig. 4

MycoBank MB516494.

Etymology: Name refers to Eucalyptus caliginosa, on which the fungus was collected.

Maculae amphigenae, subcirculares ad irregulares, brunneae. Conidiomata in foliis acervularia, subcuticularia ad epidermalia, pallide brunnea, discreta, 2-3 strata texturae angularis composita, ad $200 \mu \mathrm{m}$ diam, 150-200 $\mu \mathrm{m}$ alta. Conidiophora nulla. Cellulae conidiogenae discretae, phialidicae, cylindricae, hyalinae, rectae vel leniter curvatae, glabrae, (14.5-)16-18(-20)×4.5-6 $\mu \mathrm{m}$. Conidia elongate ellipsoidea, plerumque recta, apice late obtuso, basi abrupte angustata in hilum leniter protrudens, aseptata, hyalina, crassitunicata, minute guttulata, $(8.5-) 15-17(-19) \times(3.5-)$ 4.5-5.5 $\mu \mathrm{m}$.

Leaf spots amphigenous, subcircular to irregular, medium brown. Conidiomata on leaves acervular, subcuticular to epidermal, pale brown, separate, consisting of 2-3 layers of textura angularis, up to $200 \mu \mathrm{m}$ diam, 150-200 $\mu \mathrm{m}$ high; dehiscence irregular, by rupture of the overlying host tissues. Conidiophores absent. Conidiogenous cells arise from the inner cells of the cavity, discrete, phialidic, cylindrical, hyaline, straight to slightly curved, smooth, $(14.5-) 16-18(-20) \times 4.5-6 \mu \mathrm{m}$. Conidia elongate ellipsoidal, mostly straight, broadly obtuse at the apex, tapering abruptly to a slightly protruding basal scar, aseptate, hyaline, thick-walled, minutely guttulate, (8.5-)15-17 $(-19) \times(3.5-) 4.5-5.5 \mu \mathrm{m}$.

Specimen examined: AUSTRALIA, New South Wales, Northern Tablelands, Mt Mackenzie Nature Reserve (290504S; 1515805E) on Eucalyptus caliginosa, 1 Feb. 2007, B.A. Summerell, holotype CBS H-20301, culture extype CPC 14048=CBS 124806, CPC 14049, 14050.

Culture characteristics: Colonies on $\mathrm{OA}$ reaching $3 \mathrm{~cm}$ after $1 \mathrm{wk}$ at $25^{\circ} \mathrm{C}$ in the dark, subcircular, raised, with even margin and slightly folded surface, with dense, white aerial mycelium, partly submerged, buff to white, conidia not formed in culture.

Notes: Cryptosporiopsis caliginosa (conidia 8.5-19 $\mu \mathrm{m}$ long) is easily distinguishable from C. californiae, which has longer conidia $(12.5-27.5 \mu \mathrm{m})$. BLAST results for the ITS sequence of this species had an E-value of 0.0 with 


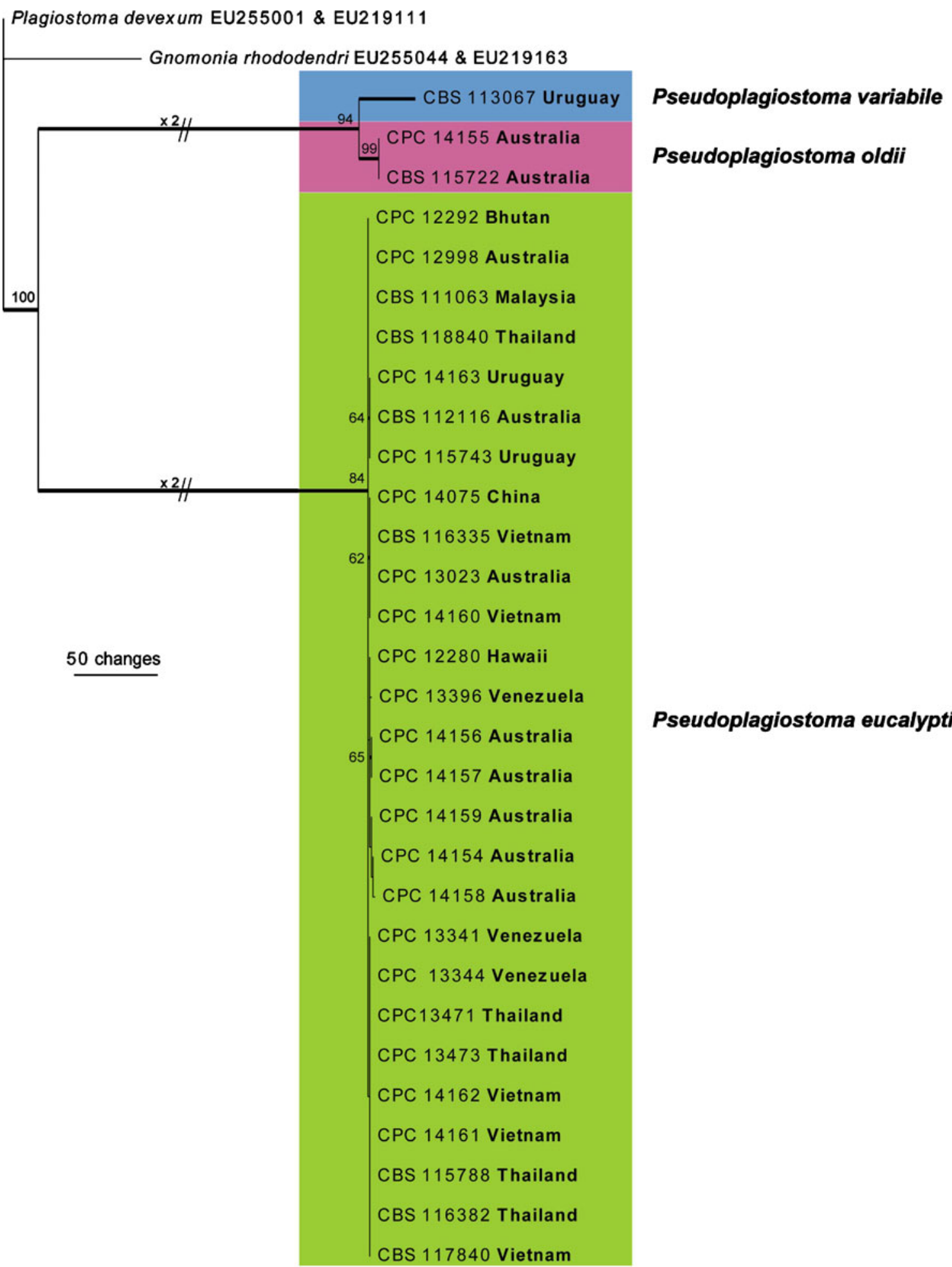

Fig. 2 The first of 212 equally most parsimonious trees obtained from a heuristic search with 100 random taxon additions of the combined ITS and TUB sequence alignment. The scale bar shows 50 changes, and bootstrap support values from 1,000 replicates are shown at the nodes. Branches present in the strict consensus tree are thickened. The tree was rooted to sequences of Plagiostoma devexum (GenBank accession ITS: EU255001; TUB: EU219111) and Gnomonia rhododendri (GenBank accession ITS: EU255044; TUB: EU219163) 
the ITS sequences of Neofabraea eucalypti (GQ303279; $97 \%$ identical), Gloeosporium sp. (EF672242; $92 \%$ identical), Coleophoma empetri (FJ480134; 92 \% identical) and others.

Pseudoplagiostomaceae Cheewangkoon, M.J. Wingf. \& Crous, fam. nov.

MycoBank MB516495.

Perithecia immersa, obliqua vel horizontalia; subglobosa vel elliptica; rostrum excentricum vel laterale, stroma non formatum. Asci unitunicati, annulo subapicali nonamyloideo, aparaphysati. Ascosporae uniseptatae, hyalinae, appendicibus terminalibus elongatis hyalinis.

Members of the Diaporthales having morphological characters of the genus Pseudoplagiostoma. Immersed, oblique to horizontal perithecia in host tissue; depressed globose or elliptical; beak eccentric to lateral; stromatic tissue not formed. Asci unitunicate, with non-amyloid subapical ring, lacking paraphyses. Ascospores hyaline, 1 -septate, with terminal, elongate, hyaline appendages.

Type genus: Pseudoplagiostoma Cheewangkoon, M.J. Wingf. \& Crous

Notes: Of the families presently known from the Diaporthales (Wehmeyer 1975; Castlebury et al. 2002; Gryzenhout et al. 2006; Rossman et al. 2007; Voglmayr and Jaklitsch 2008), the Pseudoplagiostomaceae most closely resembles the Gnomoniaceae in the morphological characters of its teleomorph, such as solitary, thin-walled, immersed ascomata with lateral beaks lacking stromata, asci with a distinct ring, and medianly 1-septate ascospores less than $25 \mathrm{~mm}$ long (Monod 1983; Castlebury et al. 2002; Sogonov et al. 2008). Phylogenetically, Pseudoplagiostro-
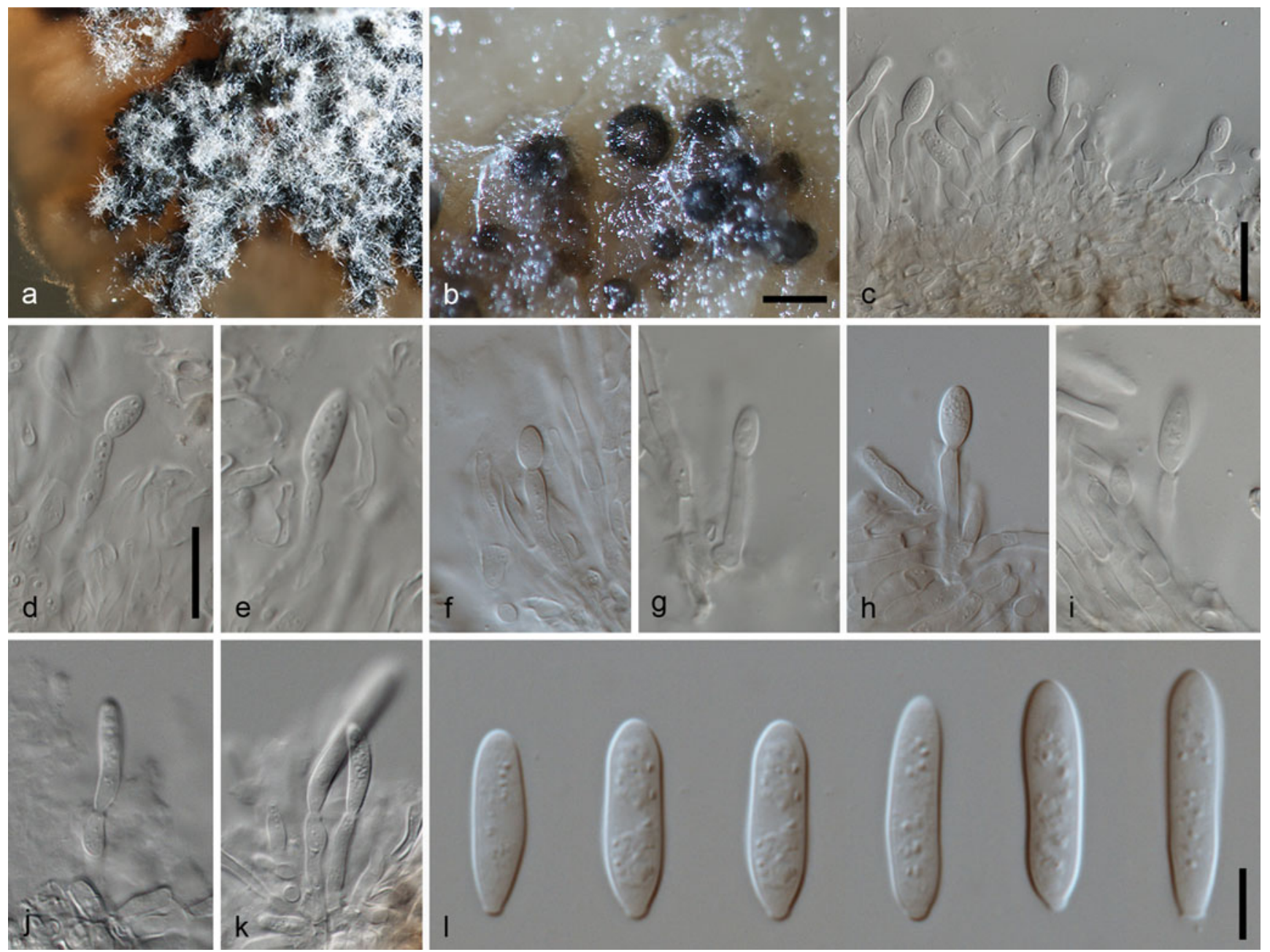

Fig. 3 Cryptosporiopsis californiae. a. Colony on MEA. b. Conidiomata on MEA. c-k. Conidia and phialidic conidiogenous cells. 1. Conidia. Scale bars: $b=150 \mu \mathrm{m}, \mathrm{c}-\mathrm{k}=15 \mu \mathrm{m}, \mathrm{l}=10 \mu \mathrm{m}$; d applies to $\mathrm{d}-\mathrm{k}$ 

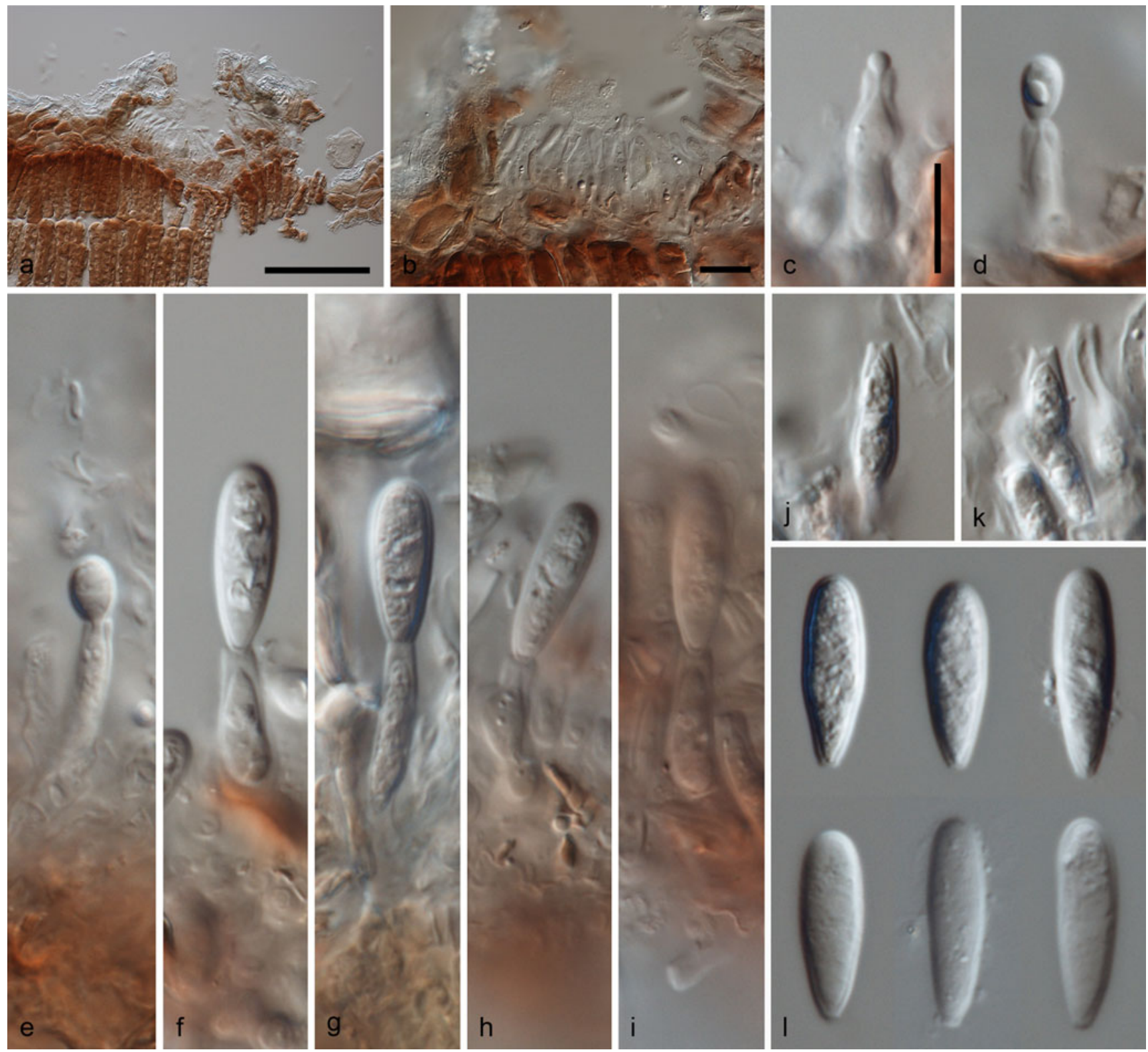

Fig. 4 Cryptosporiopsis caliginosa. a, b. Conidiomata on host substrate. c-i. Conidia attached to phialidic conidiogenous cells. j, k. Conidiogenous cells. 1 . Conidia. Scale bars: $a=100 \mu \mathrm{m}, b=20 \mu \mathrm{m}, \mathrm{c}-1=10 \mu \mathrm{m}$; c applies to $\mathrm{c}-1$

maceae is closer to families with well-developed stromatic tissue such as Diaporthaceae and Pseudovalsaceae, or families with stromatic and non-stromatic tissues such as Valsaceae and Sydowiellaceae.

Pseudoplagiostoma Cheewangkoon, M.J. Wingf. \& Crous, gen. nov.

MycoBank MB516496.

Etymology: Named reflects morphological similarity to Plagiostoma.

Ascomata perithecia, immersa, obliqua ad horizontalia, subglobosa vel elliptica, atrobrunnea ad nigra; rostrum vulgo in epiphyllo erumpens, excentricum ad laterale; ostiolum periphysatum; peridium coriaceum, stroma non formatum. Asci subcylindrici ad elongate obovoidei, aparaphysati, unitunicati, annulo subapicali nonamyloideo. Ascosporae hyalinae, ellipsoideae, utrinque rotundatae, plerumque rectae, in medio uniseptatae, glabrae, appendicibus terminalibus elongatis hyalinis. Conidiomata acervularia ad pycnidialia, subcuticularia ad epidermalia, paries texturae angularis compositus. Conidiophora nulla. Cellulae conidiogenae cylindricae ad ampulliformes, enteroblasticaliter proliferentes, tunica periclinaliter incrassata colluloque, vel parte apicali percurrenter 
proliferentes. Conidia holoblastica, ellipsoidea, apice obtuso et basi hilo plano protrudente, continua.

Ascomata perithecial, immersed in host tissue, oblique to horizontal, depressed globose or elliptical, dark brown to black; beak usually erumpent epiphyllously, eccentric to lateral; ostiole lined with periphyses; peridium coriaceous, with sparse hyphae visible growing into the host tissue; stromatic tissue not formed. Asci subcylindrical to long
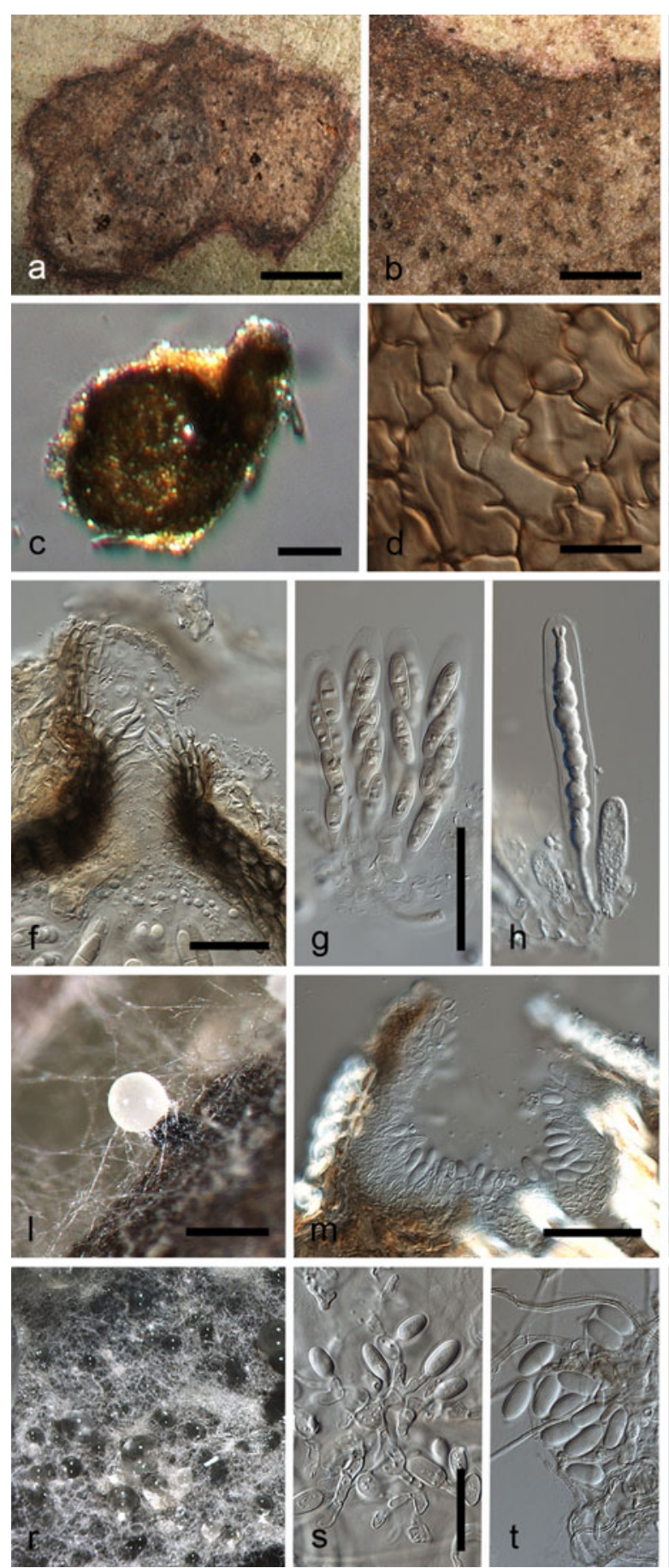
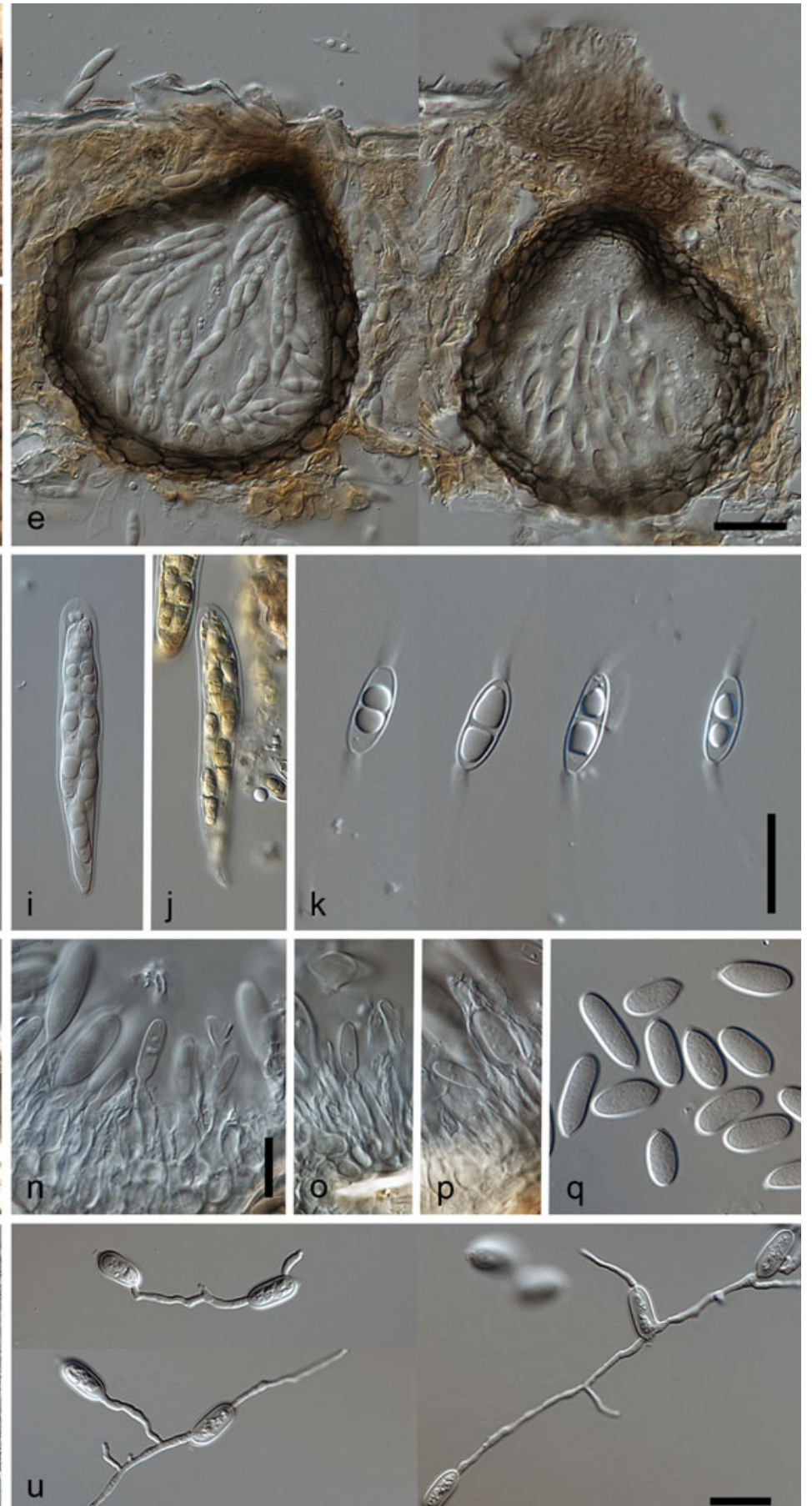

Fig. 5 Pseudoplagiostoma eucalypti. a. Leaf spot. b, c. Ascomata. d. Ascomatal wall. e. Cross section though ascomata. f. Ostiole. g. Asci. h. Young ascus. i. Mature ascus. j. Ascus strained in Melzer's reagent, showing non-amyloid subapical ring. k. Ascospores. 1. Conidiomata. $\mathrm{m}$. Cross section though conidiomata. $\mathrm{n}-\mathrm{p}$. Conidia attached to conidiogenous cells with percurrent proliferation. q. Conidia. r.

Colony on MEA. s, t. Conidia and conidiogenous cells. u. Microcyclic conidiation. a-k: From Eucalyptus leaves. 1-q: From PNA. r-u: From MEA. Scale bars: $a=5 \mathrm{~mm}, b=1 \mathrm{~mm}, \mathrm{c}, \mathrm{e}=50 \mu \mathrm{m}, d=5 \mu \mathrm{m}, \mathrm{f}-\mathrm{j}=$ $30 \mu \mathrm{m}, \mathrm{k}, \mathrm{s}-\mathrm{u}=20 \mu \mathrm{m}, \mathrm{l}=200 \mu \mathrm{m}, m=70 \mu \mathrm{m}, \mathrm{n}-\mathrm{q}=15 \mu \mathrm{m}$; g applies to $\mathrm{g}-\mathrm{j} ; \mathrm{n}$ applies to $\mathrm{n}-\mathrm{q} ; \mathrm{s}$ applies to $\mathrm{s}-\mathrm{t}$ 
obovoid, lacking paraphyses, unitunicate, with non-amyloid subapical ring, wedge-shaped, refractive, with canal leading to the apex. Ascospores hyaline, ellipsoidal, tapering towards rounded ends, usually straight, medianly 1-septate, wall smooth, with terminal, elongate, hyaline appendages. Conidiomata acervular to pycnidial, subcuti cular to epidermal, wall composed of textura angularis. Conidiophores absent. Conidiogenous cells cylindrical to ampulliform, proliferating enteroblastically with periclinal thickening and collarette, or percurrently proliferating in the apical part. Conidia holoblastic, ellipsoid, with obtuse apex and a flat protruding scar at the base, 0 -septate.

Type species: Pseudoplagiostoma eucalypti Cheewangkoon, M.J. Wingf. \& Crous

Pseudoplagiostoma eucalypti Cheewangkoon, M.J. Wingf. \& Crous, sp. nov. Figs. 5, 6

MycoBank MB516497.

Anamorph: "Cryptosporiopsis" eucalypti Sankaran \& B. Sutton, Mycol. Res. 99: 828. 1995.

Maculae amphigenae, subcirculares ad irregulares, brunneae et atrobrunneae. Ascomata epigena immersa ad semiimmersa, intraepidermalia vel subepidermalia, subglobosa vel elliptica, coriacea, (90-)100-130(-170) $\mu \mathrm{m}$ lata, (120-)130-150(-190) $\mu \mathrm{m}$ alta, atrobrunnea ad nigra; ostiolum laterale, rostratum (50-)60-65(-70) $\mu \mathrm{m}$ latum, papillatum, usqua ad $105 \mu \mathrm{m}$ longum, periphysatum. Peridium 2-4 strata texturae angularis atrobrunneae compositum. Asci aparaphysati, unitunicati, octospori, apice rotundati, subcylindrici ad elongate obovoidei, annulo subapicali nonamyloideo, $(60-) 65-70(-80) \times(10-)$ 11-13(-14) $\mu \mathrm{m}$. Ascosporae ellipsoideae, utrinque rotundatae, septo latissimae, hyalinae, in medio uniseptatae; $(15-) 17-19(-21) \times(5-) 6(-7) \mu \mathrm{m}$; maturitate appendicibus cylindricis terminalibus elongatis, 5.5-7 $\mu \mathrm{m}$ latis, (8-)15$20(-30) \mu \mathrm{m}$ longis. Conidiomata brunnea ad atrobrunnea, acervularia ad pycnidialia, subglobosa ad late ovoidea, subcuticularia ad epidermalia, discreta, 2-4 strata texturae angularis medio brunneae composita, (170-)180200(-230) $\mu \mathrm{m}$ lata, (150-)170-190(-220) $\mu \mathrm{m}$ alta. Conidiophora nulla. Cellulae conidiogenae enteroblasticaliter proliferentes, phialidis similes tunica periclinaliter incrassata colluloque, vel parte apicali percurrenter proliferentes, hyalinae, glabrae, cylindricae ad ampulliformes, rectae vel leniter curvatae, $(6-) \quad 8-12(-15) \times 2-4(-6) \mu \mathrm{m}$. Conidia holoblastica, hyalina, guttulata, glabra, cassitunicata, ellipsoidea, continua, apice obtuso, leniter curvata, basi hilo plano protrudente angustata, $(15-) 17-19(-23) \times(6.5-)$ 7-8(-8.5) $\mu \mathrm{m}$.

Etymology: Name refers to the fact that the fungus occurs on Eucalyptus.

Leaf spots amphigenous, subcircular to irregular, medium brown with blackish brown, reverse medium brown,
3-20 $\mathrm{mm}$ diam, surrounded by a purple-brown margin, which is dark brown in reverse. Mycelium immersed, consisting of smooth, septate, branched, medium brown, 2-3.5 $\mu \mathrm{m}$ wide hyphae. Ascomata epigenous immersed to semi-immersed, intra- or subepidermal, visible as minute ostiolar dots, depressed globose or elliptical, coriaceous, $(90-)$ 100-130(-170) $\mu \mathrm{m}$ wide, (120-)130-150(-190) $\mu \mathrm{m}$ high, dark brown to black; ostiole lateral, beaked, (50-)60-65 $(-70) \mu \mathrm{m}$ wide, papillate, up to $105 \mu \mathrm{m}$ long, periphysate; wall consisting of 2-4 layers of dark brown textura angularis. Asci aparaphysate, unitunicate, 8-spored, apically rounded, subcylindrical to long obovoid, sessile or subsessile in young asci, slightly curved, with non-amyloid subapical ring, (60-)

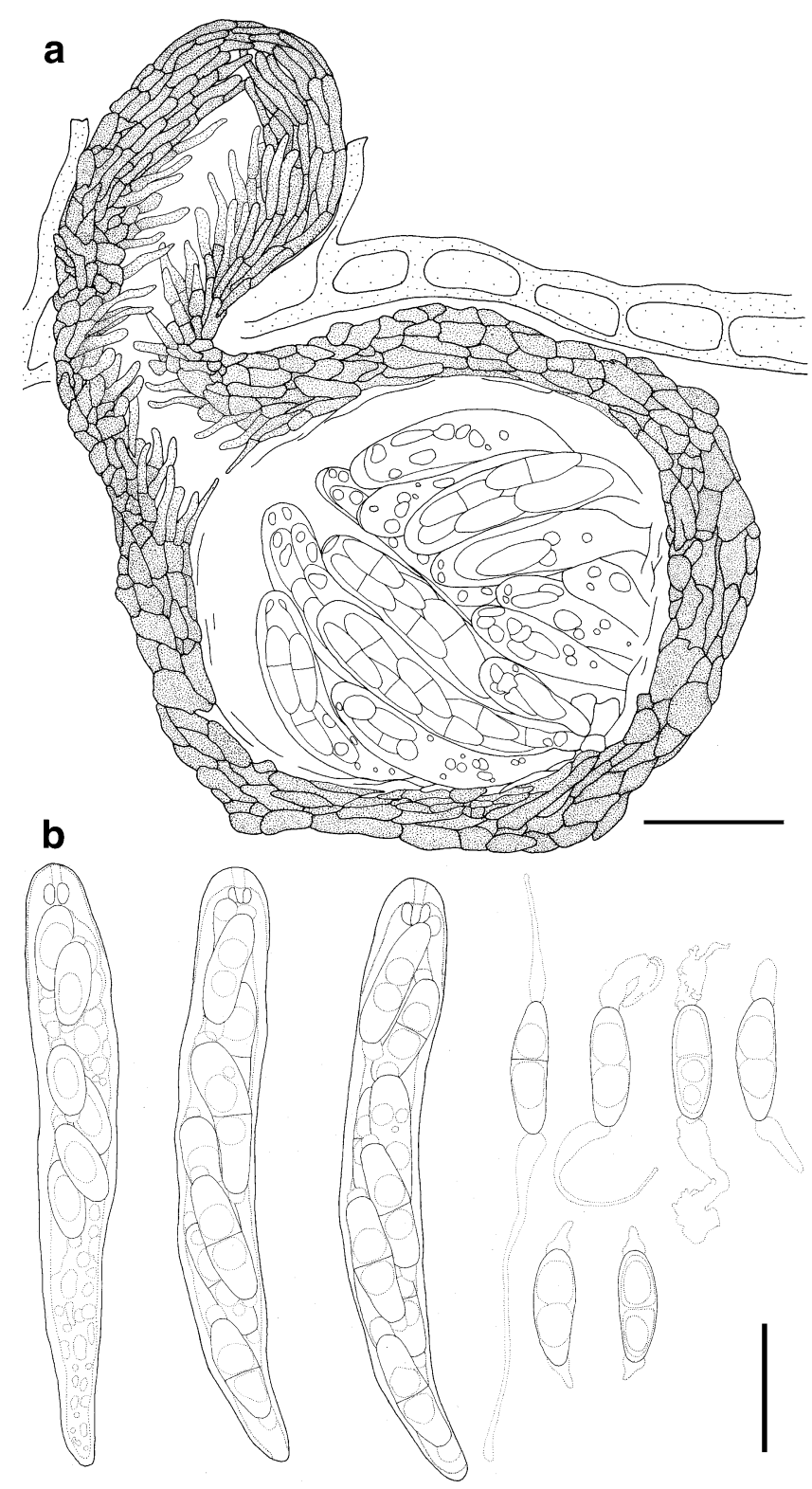

Fig. 6 Line drawing. Pseudoplagiostoma eucalypti. a. Cross section though ascoma. b. Asci; c. Ascospores. Scale bars: $a=30 \mu \mathrm{m}, \mathrm{b}-\mathrm{c}=$ 15; c applies to $\mathrm{b}-\mathrm{c}$ 
65-70(-80) $\times(10-) 11-13(-14) \mu \mathrm{m}$. Ascospores ellipsoid, tapering to rounded ends, widest at septum, hyaline, bi- to tri-seriate overlapping, fasciculate, medianly 1-euseptate; not constricted at the septum, with 1-2 large guttules in each cell, thin-walled, straight, (15-)17-19(-21) $\times(5-) 6(-7) \mu \mathrm{m}$; with hyaline, cylindrical appendages at both polar ends at maturity, expanded at the base, tapering towards the apex, 5.5-7 $\mu \mathrm{m}$ wide, (8-)15-20(-30) $\mu \mathrm{m}$ long. Conidiomata medium to dark brown, acervular to pycnidial, with pale yellow drops of exuding conidia (at times forming a short cirrus); subglobose to broadly ovoid, subcuticular to epidermal, separate, consisting of 2-4 layers of medium brown textura angularis, (170-)180-200(-230) $\mu \mathrm{m}$ wide, (150-) 170-190(-220) $\mu \mathrm{m}$ high; wall 15-20 $\mu \mathrm{m}$ thick, with central rupture, breaking through plant tissue, $(50-) 60-80(-100) \mu \mathrm{m}$ wide. Conidiophores absent. Conidiogenous cells proliferat-

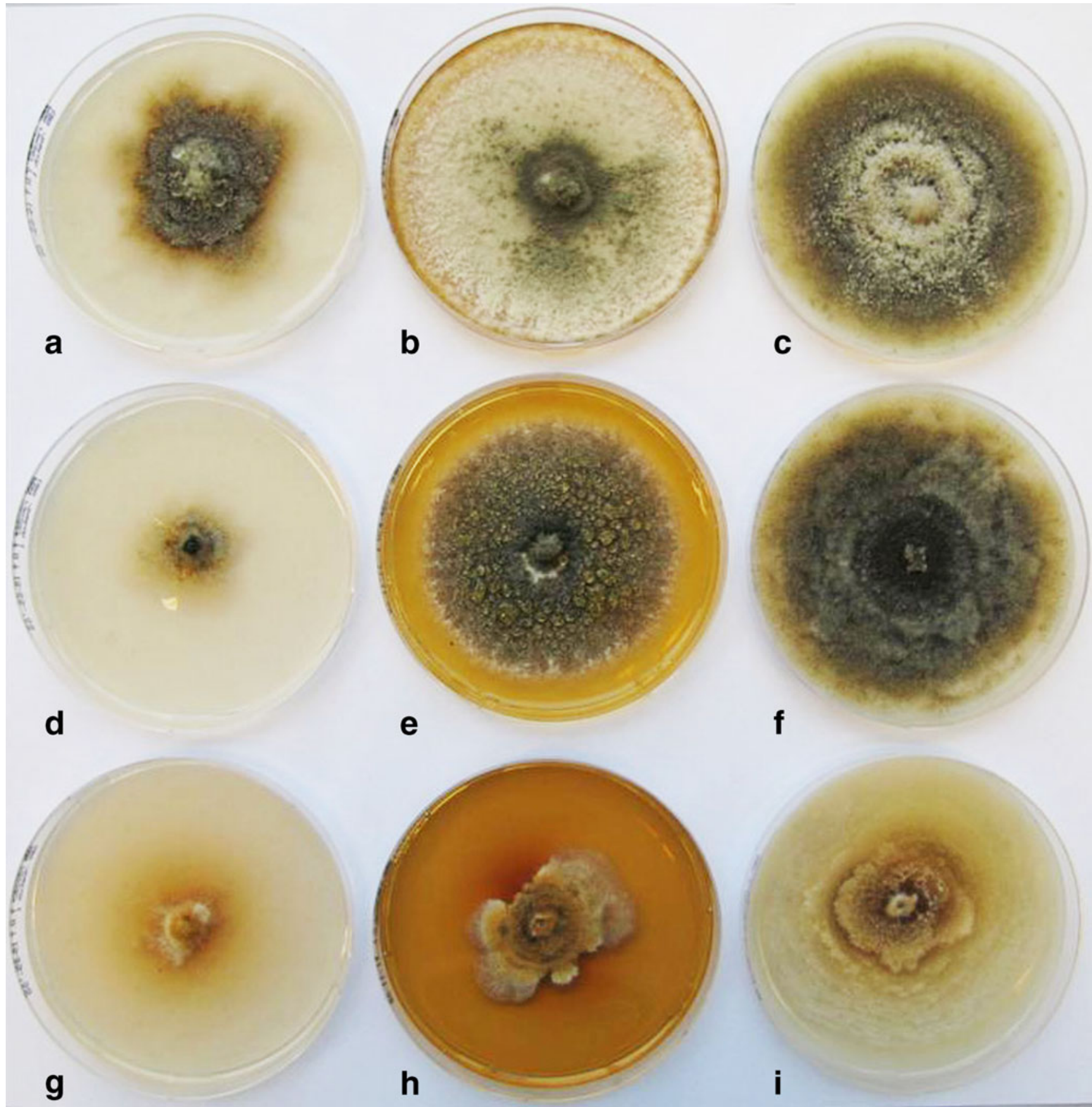

Fig. 7 Pseudoplagiostoma spp. in culture after 15 d. a-c. Ps. eucalypti (CBS 115788). a. On OA. b. On MEA. c. On PDA. d-f. Ps. oldii (CBS 124808). d. On OA. e. On MEA; f. On PDA. g-i. Ps. variabile (CBS 113067). g. On OA; h. On MEA; i. On PDA; g-i 


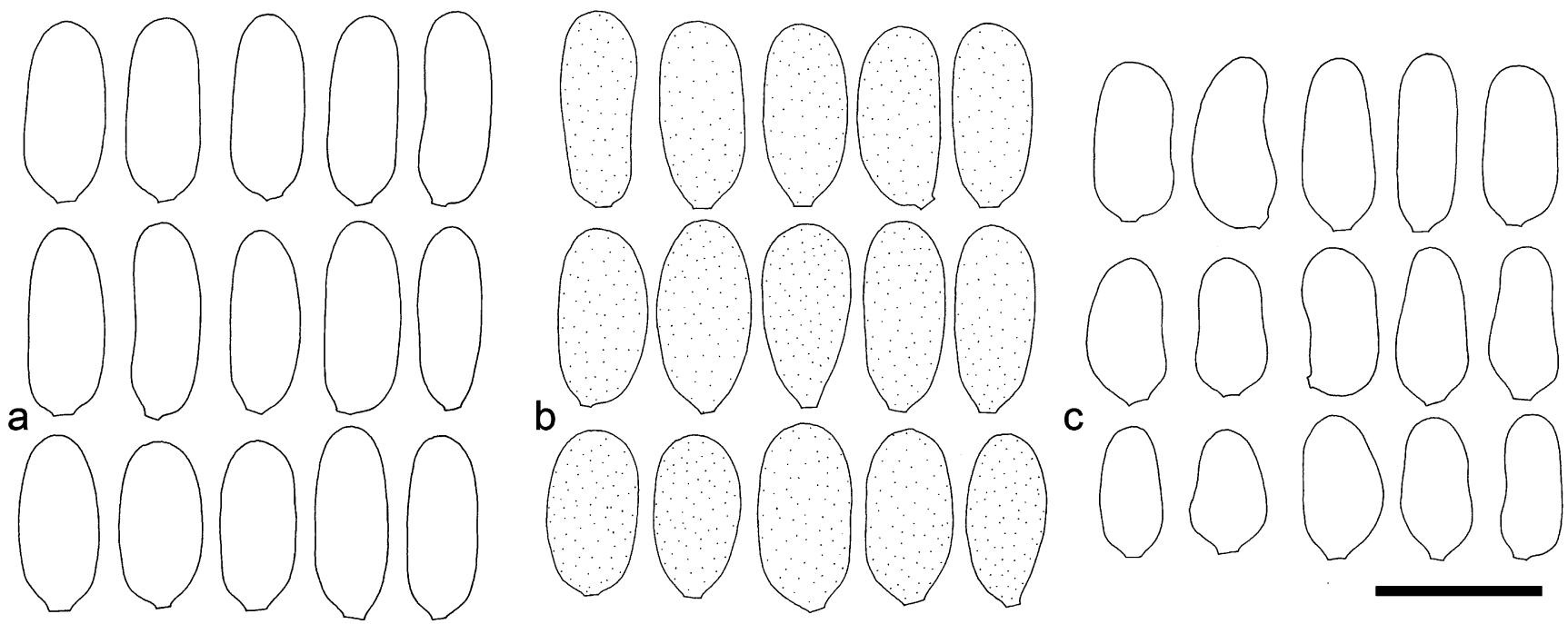

Fig. 8 Line drawing. Conidia of Pseudoplagiostoma spp. on MEA. a. Ps. eucalypti; b. Ps. oldii. c. Ps. variabile. Scale bar:=10 $\mu \mathrm{m}$

ing enteroblastically, appearing as phialides with periclinal thickening and collarette, or with percurrent proliferation in the apical part; discrete, arising from the inner cell layer, hyaline, smooth, cylindrical to ampulliform, wider at the base, straight or slightly curved, $(6-) 8-12(-15) \times 2-4$ (-6) $\mu \mathrm{m}$. Conidia holoblastic, hyaline, guttulate, smooth, thick-walled, ellipsoid, aseptate, slightly curved, frequently slightly narrow at the middle, with obtuse apex; base tapering to flat protruding scar, $(15-) 17-19(-23) \times(6.5-) 7-8$ $(-8.5) \mu \mathrm{m}$; on MEA, (14-)16-19(-22)×(6-)7-9(-11) $\mu \mathrm{m}$.

Ascospore germination: Ascospores germinate from the apical cell, with primary germ tubes forming near the apex; secondary germ tubes form later from the second cell, remaining hyaline; cell wall becoming slightly thicker, but not constricted at the septum, showing no distortion.

Culture characteristics: Characteristics on MEA, PDA and $\mathrm{OA}$ of all three species of Pseudoplagiostoma are compared in Table 2 and Figs. 7, 8.

Specimens examined: VENEZUELA, on living leaves of Eucalyptus urophylla, Oct. 2006, M.J. Wingfield, holotype of Ps. eucalypti, CBS H-20303, cultures ex-type CPC $13341=$ CBS 124807, CPC 13342, 13343. HAWAII, Kauai, on Eucalyptus grandis, 23 May 1978, C.S. Hodges, holotype of Cryptosporiopsis eucalypti, IMI $237416 \mathrm{f}$.
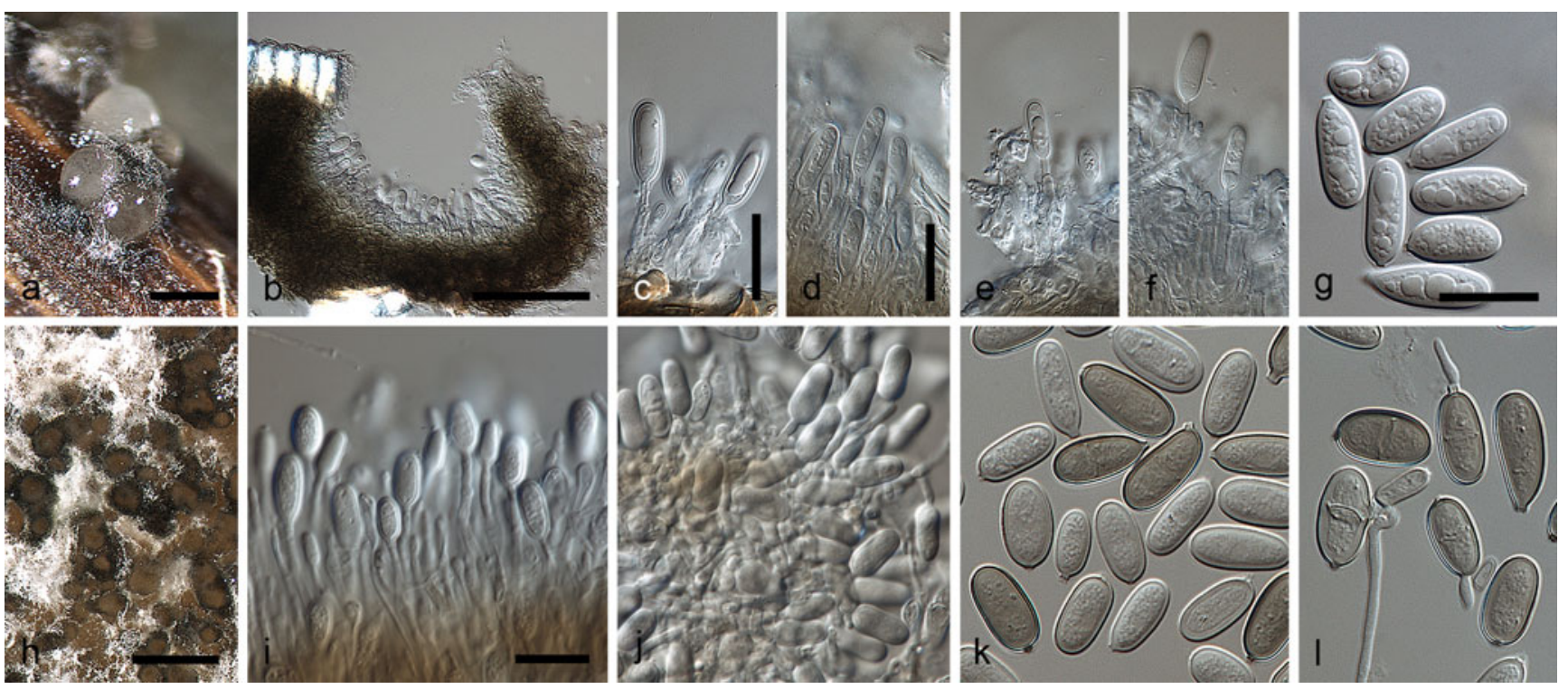

Fig. 9 Pseudoplagiostoma oldii. a. Conidiomata. b. Cross section though conidiomata; $\mathrm{c}-\mathrm{f}$. Conidia attached to conidiogenous cells with percurrent proliferation; g. Conidia; h. Conidiomata; i-j. Conidia and conidiogenous cells; $\mathrm{k}$. Conidia; 1 . Germinating conidia. a-g: on PNA. $\mathrm{h}-\mathrm{l}$ : on MEA. Scale bars: a, $h=800 \mu \mathrm{m}, b=100 \mu \mathrm{m}, \mathrm{c}-\mathrm{g}, \mathrm{k}-1=20 \mu \mathrm{m}$, $\mathrm{i}-\mathrm{j}=15 \mu \mathrm{m}$; $\mathrm{d}$ applies to $\mathrm{d}-\mathrm{f}$; $\mathrm{g}$ applies to $\mathrm{g}, \mathrm{k}-\mathrm{l}$; $\mathrm{i}$ applies to $\mathrm{i}-\mathrm{j}$ 
Pseudoplagiostoma oldii Cheewangkoon, M.J. Wingf. \& Crous, sp. nov. Fig. 9

MycoBank MB 516498.

Etymology: Named for Australian forest pathologist, Dr Ken Old, who contributed substantially to an understanding of Eucalyptus diseases including the Cryptos poriopsis disease complex.

Ascomata non vidimus. Species haec a Ps. eucalypti et Ps. variabili differt conidiomatibus (265-)285-300(-330) $\mu \mathrm{m}$ latis et (200-)220-250(-270) $\mu \mathrm{m}$ altis et conidiis maturitate brunneis in agaro extracto malti, $(15-) 17-20(-23) \times(6-) 7-$ $8(-9) \mu \mathrm{m}$.

Leaf spots amphigenous, subcircular to irregular, medium brown. Ascomata not observed. On PNA dark brown conidiomata appeared after $15 \mathrm{~d}$ in the dark; conidiomata acervular to pycnidial, with pale grey masses of conidia, subglobose to broadly ovoid, subcuticular to epidermal, separate, consisting of 3-5 layers of dark brown textura angularis, (265-)285-300(-330) $\mu \mathrm{m}$ wide, (200-)220-250 $(-270) \mu \mathrm{m}$ high; central opening, (90-)110-120(-140) $\mu \mathrm{m}$ wide, wall 20-30 $\mu \mathrm{m}$ thick. Conidiophores absent. Conidiogenous cells discrete, phialidic with periclinal thickening, or 1-3 apical percurrent proliferations; cylindrical to ampulliform, arising from the inner cell layer, hyaline but at maturity brown on MEA, straight or slightly curved, wider at the base, smooth, $(8.5-) 15-20(-26) \times 2-3(-4.5) \mu \mathrm{m}$. Conidia holoblastic, hyaline, guttulate, smooth, thickwalled, ellipsoidal, aseptate, slightly curved, apex obtuse, base tapering to a flat, protruding scar, (15-)17-20(-23) $\times(6-) 7-8(-9) \mu \mathrm{m}$; on MEA, $(11-) 14-17(-20) \times(6-) 7$ $-9(-11) \mu \mathrm{m}$.

Specimens examined: AUSTRALIA, Queensland, Lannercost, on Eucalyptus camaldulensis, 6 Jan. 2007, K. Old, holotype CBS H-20300, cultures ex-type CBS 124808= CMW 6675, CPC 14155; on E. camaldulensis, Jan. 2007, K. Old, CBS 115722.
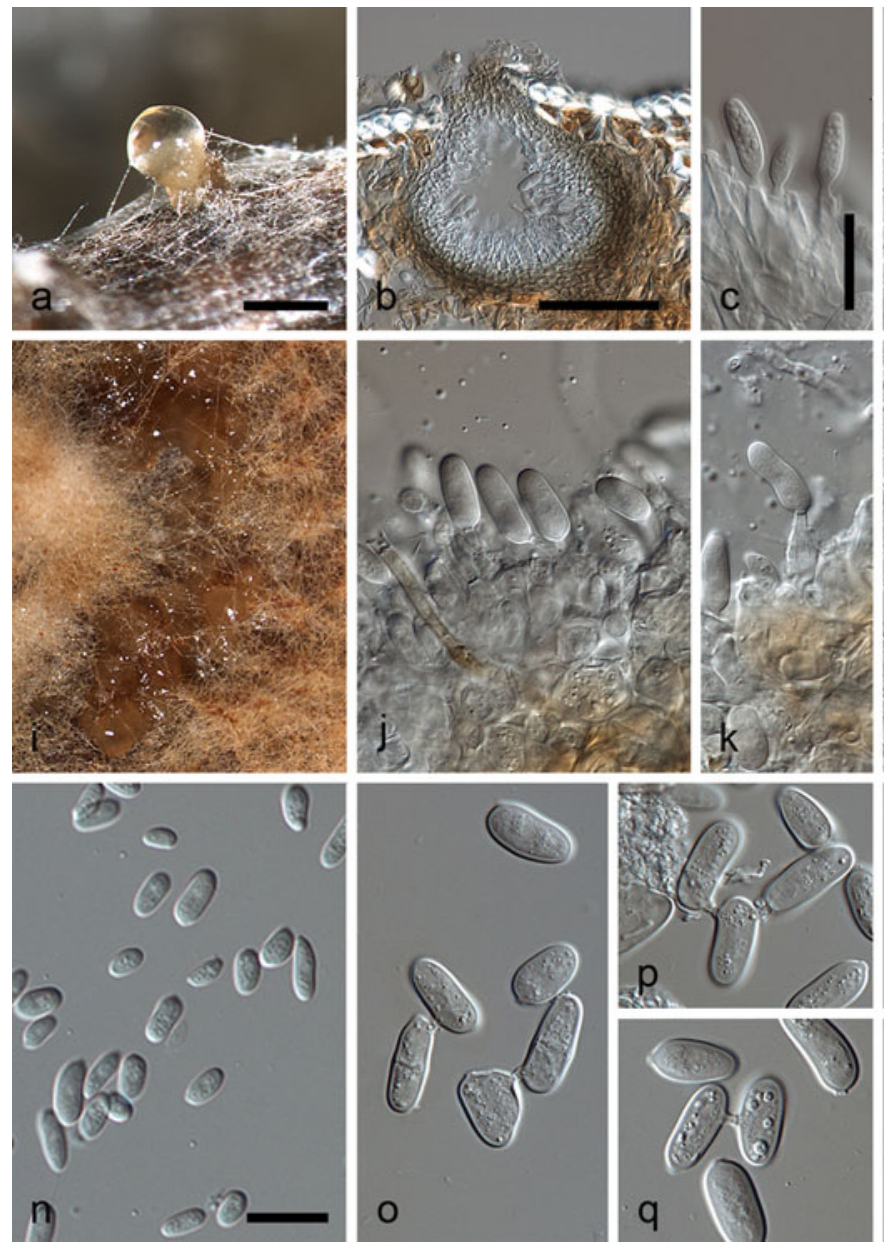

Fig. 10 Pseudoplagiostoma variabile. a. Conidiomata; b. Cross section through conidiomata; c-g. Conidia attached to conidiogenous cells with percurrent proliferation; h. Conidia; i. Conidiomata; $\mathrm{j}-\mathrm{m}$. Conidia and conidiogenous cells; n. Conidia; o-s.
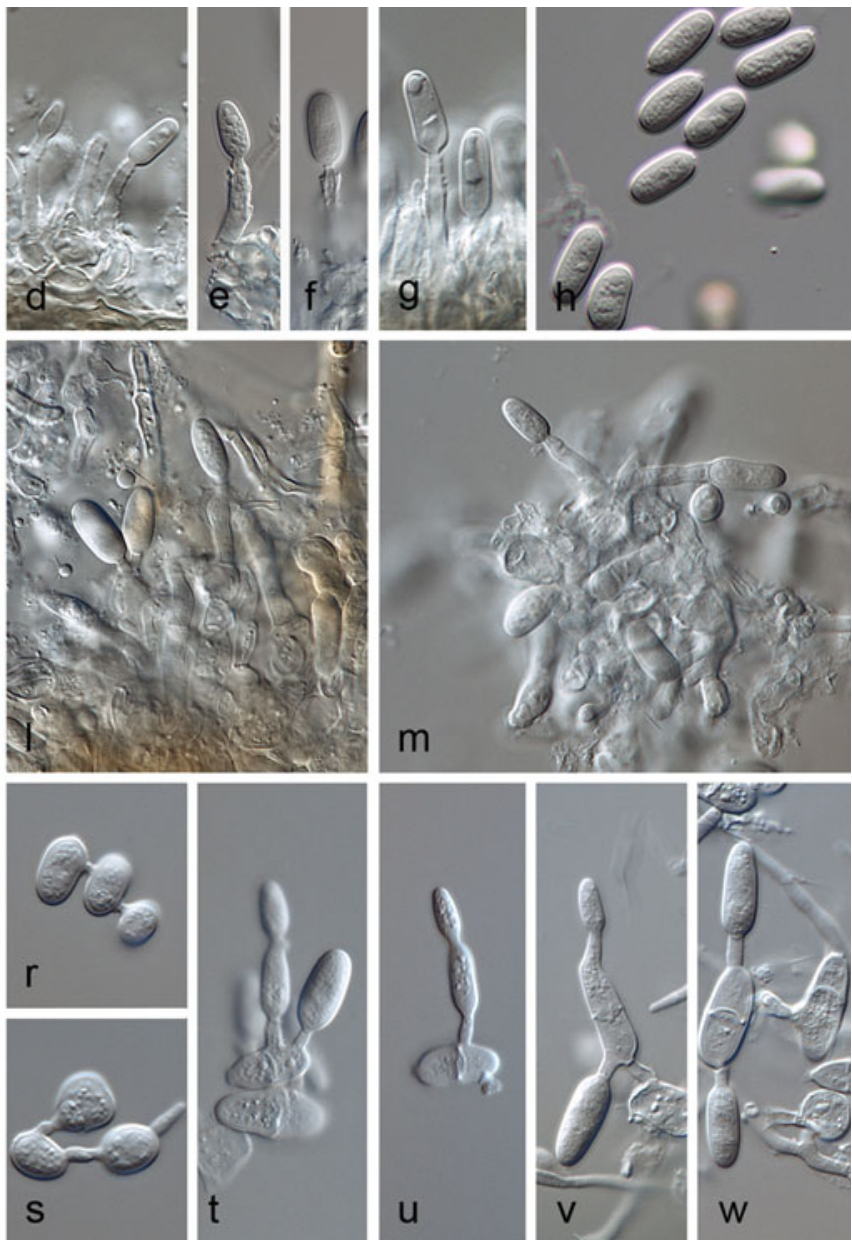

Conidial anastomosis; $\mathrm{t}-\mathrm{w}$. Microcyclic conidiation. a-h: on PNA. i-w: on MEA. Scale bars: $a=800 \mu \mathrm{m}, b=100 \mu \mathrm{m}, \mathrm{c}-\mathrm{w}=20 \mu \mathrm{m}, \mathrm{c}$ applies to $\mathrm{c}-\mathrm{m}, \mathrm{O}-\mathrm{W}$ 
Pseudoplagiostoma variabile Cheewangkoon, M.J. Wingf. \& Crous, sp. nov. Fig. 10

MycoBank MB516499.

Etymology: Name reflects the variable conidial shape in this fungus.

Ascomata non vidimus. Species haec a Ps. eucalypti et PS. oldii differt conidiomatibus (145-)170-190(-245) $\mu \mathrm{m}$ latis et $(130-) 160-180(-230) \mu \mathrm{m}$ altis, et conidiis unitunicatis, $(12.5-) 15.5-17.5(-23.5) \times(5.5-) 6.5-8(-9) \mu \mathrm{m}$.

Leaf spots amphigenous, subcircular to irregular, medium brown. Ascomata not observed. On PNA medium to dark brown pycnidial conidiomata appeared after $15 \mathrm{~d}$ of incubation in the dark, exuding pale yellow conidial masses; conidiomata subglobose to broadly ovoid, subcuticular to epidermal, separate, consisting of 2-4 layers of medium brown textura angularis, (145-)170-190(-245) $\mu \mathrm{m}$ wide, (130-)160-180(-230) $\mu \mathrm{m}$ high, apical ostiole central, (60-) 70-90(-110) $\mu \mathrm{m}$ wide; wall 15-25 $\mu \mathrm{m}$ thick. Conidiophores absent. Conidiogenous cells discrete, phialidic with periclinal thickening, or 1-5 apical percurrent proliferations; cylindrical to ampulliform, arising from the inner cell wall, hyaline, straight or slightly curved, wider at the base, smooth, (12-)15-20(-23) ×2-3(-4.5) $\mu \mathrm{m}$. Conidia holoblastic, hyaline, guttulate, smooth, thin to slightly thick-walled, ellipsoid, aseptate, slightly curved, frequently constricted in the middle, apex obtuse, base tapering to flat protruding scar, (12.5-)15.5-17.5(-23.5) $\times(5.5-) 6.5-8(-9) \mu \mathrm{m}$; on MEA, (6.5-)15.5-17(-19)×(6.5-)7.5-9(-10.5) $\mu \mathrm{m}$.

Specimen examined: URUGUAY, on Eucalyptus globulus, 5 Aug. 2002, M.J. Wingfield, holotype CBS H-20304, cultures ex-type CBS 113067=CPC 5320, CPC 5321.

\section{Key to species of Pseudoplagiostoma*}

1. Conidia turn brown at maturity, $(11-) 14-17(-20) \times(6-)$ $7-9(-11) \mu \mathrm{m}$, ratio $(1.9-) 2.3-2.5: 1 \quad$ (1:w) Ps. oldii

1. Conidia remain hyaline at maturity, ratio $2-2.1: 1$ (l:w) ................................................. 2

2. Conidia ellipsoid, (14-) $16-19(-22) \times(6-) 7-9(-11) \mu \mathrm{m}$, ratio $2.1: 1(1: w)$......................... Ps. eucalypti

2. Conidia variable in shape, subglobose to bean-shaped, $(6.5-) 15.5-17(-19) \times(6.5-) 7.5-9(-10.5) \mu \mathrm{m}$, ratio $2: 1$ $(1: w)$ Ps. variabile

*Sporulating on MEA in culture.

\section{Discussion}

Results of this study have elucidated considerable confusion that has surrounded the taxonomy of one of the fungal pathogens most commonly encountered on leaves of Eucalyptus in plantations globally. Phylogenetic inference of DNA sequence data thus showed that the fungus known as Cryptosporiopsis eucalypti and encountered in many treatments of Eucalyptus diseases (Sharma 1994; Sankaran et al. 1995; Old et al. 2002, 2003) is the anamorph of a member of the Diaporthales (99\% bootstrap support), and not the Dermateaceae (Helotiales) along with Crypto sporiopsis s. str. The Eucalyptus pathogen that has been treated as $C$. eucalypti since 1995 has thus been placed in a novel genus as Pseudoplagiostroma eucalypti.

This study includes 39 isolates collected from Eucalyptus in plantations on four continents and from 10 countries. The combined sequence data sets for this collection of isolates delineate three distinct species within a monophyletic lineage. The major clade (P. eucalypti) includes 27 isolates, while the second clade $(P$. oldii) includes two isolates (CBS 124808 and CBS 115722) and the third clade (P. variabile) consists of a single isolate, CBS 113067. The monophyly of Pseudoplagiostoma is strongly supported by morphological characteristics. While all three species are very similar on OA, PDA, and PNA, they can easily be distinguished in culture on MEA. The conidial wall of Ps. oldii turns brown at maturity, suggesting that this feature can be used to distinguish them (also on PNA and OA, but not on PDA). Colonies of Ps. variabile grow more slowly than those of Ps. eucalypti and Ps. oldii. It produces fewer conidia on MEA, undergoes microcyclic conidiation, and its conidia are not uniform, ranging from subglobose to ellipsoid. These features should make this widely distributed group of fungi easy to identify in Eucalyptus disease surveys.

Within the Diaporthales, Pseudoplagiostoma is more similar to members of the Gnomoniaceae based on the morphological characters of its teleomorph, such as solitary, thin-walled, immersed ascomata with lateral beaks lacking stromata, asci with a distinct ring, and medianly 1-septate ascospores less than $25 \mathrm{~mm}$ long (Monod 1983; Barr 1978; Samuels and Blackwell 2001; Castlebury et al. 2002; Sogonov et al. 2008). In contrast, in the Valsaceae and Sydowiellaceae, stromatic and nonstromatic tissues are present (Wehmeyer 1975; Rossman et al. 2007). Also, in other families of Diaporthales such as Cryphonectriaceae, Diaporthaceae, Melanconidaceae and Pseudovalsaceae, the stromatic tissues are often welldeveloped (Castlebury et al. 2002; Gryzenhout et al. 2006; Voglmayr and Jaklitsch 2008). The coelomycetous anamorph of Pseudoplagiostoma (previously reported as $C$. eucalypti) also has acervular to pycnidial conidiomata without a well-developed stroma, phialidic and annellidic conidiogenous cells, and aseptate conidia, which are features typical of the Diaporthales (Rossman et al. 2007). 
Pseudoplagiostoma is morphologically most similar to Plagiostoma in the Gnomoniaceae. It is, however, distinct from Plagiostoma and other members of the Gnomiaceae in having a truly lateral instead of a marginal neck, and distinct appendages at both ends of its ascospores. However, it shares some features with Plagiostoma, such as oblate perithecia with a single neck, but lacking a clypeus, and thin-walled asci with a conspicuous apical ring containing medianly 1-septate ascospores (Sogonov et al. 2008). Pseudoplagiostoma developed Gnomoniaceae-like morphological characters, which can be the result of convergent evolution. Phylogenetically, Pseudoplagiostroma is more closely related to families with welldeveloped stromatic tissue such as Diaporthaceae and Pseudovalsaceae; or families with stromatic and nonstromatic tissues such as Valsaceae and Sydowiellaceae. This indicates that the presence (or absence) of stromata and its development should not be over emphasised when distinguishing families within Diaporthales. Castlebury et al. (2002) also emphasised that stromatal development and thickness of the ascospore wall are of less importance than formerly suggested by Barr (1987, 1990).

Phylogenetic analysis based on LSU sequences indicated that Pseudoplagiostoma does not reside with Plagiostoma or any genus in the Gnomoniaceae, but represents a distinct clade in the Diaporthales. The genus Pseudoplagiostoma contains teleomorphic fungi with horizontal, dark, softtextured perithecial ascomata lacking stromatic tissues, but with a lateral ostiolar neck; distinct non-amyloid asci with a refractive apical ring; eight medianly 1-septate ascospores, which have elongated appendages at both ends, but lacking true paraphyses. A new family, Pseudoplagiostomaceae, is thus described to accommodate Pseudoplagiostoma in the Diaporthales.

Anamorphs of Diaporthales are generally coelomycetous, producing phialidic, often annellidic conidiogenous cells, and usually have aseptate conidia in acervular or pycnidial conidiomata, with or without a well-developed stroma (Rossman et al. 2007). Cryptonectriaceae, Diaporthaceae, Gnomoniaceae, Schizoparmeaceae and Valsaceae anamorphs produce phialides, while only Melanconidaceae and Pseudovalsaceae produce annellidic conidiogenous cells. Sydowiellaceae includes taxa with both phialidic and annellidic conidiogenous cells. According to the descriptions by Verkley (1999), Cryptosporiopsis species generally have acervular or eustromatic conidiomata. Their conidiogenous cells are determinate and phialidic, with no proliferation or formation of consecutive conidia at progressive levels. These leave a series of scars on the cell apex, with periclinal thickening often seen in vitro. Pseudoplagiostoma anamorphs are difficult to distinguish morphologically from Cryptosporiopsis s. str. based on this widely-used generic concept. In this study, the three species of Pseudoplagiostoma produced conidiogenous cells that proliferated percurrently, with conidia seceding at the same level or higher, and lacking the swollen structure observed below the conidiogenous loci seen in Cryptosporiopsis anamorphs linked to Pezicula (Verkley 1999). This difference in conidiogenesis could, therefore, be used to distinguish anamorphs of Pseudoplagiostoma from other similar coelomycetous genera in the Diaporthales, and from those in the Helotiales.

Moreover, based on LSU and ITS sequence data, three species of Cryptosporiopsis (C. californiae, C. caliginosa and Cryptosporiopsis sp.) clustered with other members of Pezicula and Cryptosporiopsis within the Dermateaceae (Helotiales). Thus far, only one true other Cryptosporiopsis species (C. edgertonii) has been reported from Eucalyptus samples in New Zealand (Gadgil 2005), which has much larger conidia $(30-48 \times 12-15 \mu \mathrm{m}$; Edgerton 1908) than these taxa.

Phenotypic plasticity remains a major factor leading to taxonomic uncertainty in the classification and identification of diaporthalean fungi. Castlebury et al. (2002) noted that the delimitation of diaporthalean families varied considerably among specialists, and that their morpho logical characters could easily lead to confusion for nonspecialists. Nine diaporthalean families were previously established based on phylogenetic analysis, because it highlighted the specific differences observed among species at molecular level (Rossman et al. 2007).

For Pseudoplagiostomaceae, we found that certain morphological characters are more valuable for species distinction, such as conidia, conidiogenous cells and conidiomata of anamorphs. However, only the ascomatal neck and asci-forming positions could be used to distinguish these teleomorphs from those in other families. It should be noted though, that the phylogeny of the Diaporthales is still not fully resolved (Castlebury et al. 2002). The addition of new taxa and description of potential new genera may result in changes in relative relatedness between families. This may also indicate differences in the importance of certain morphological characteristics to delineate families.

This study has resolved the taxonomy of one of the most commonly encountered fungi emerging from Eucalyptus disease surveys. The results will contribute substantially to a better understanding of these fungi and their role in Eucalyptus leaf diseases in many different parts of the world. A priority at this stage will be to compare the pathogenicity of the three new species of Pseudoplagiostoma that have previously been treated as the single species, C. eucalypti. The temptation to assume that they are all pathogens should be avoided until Koch's postulates have been proven. Furthermore, it would be useful to have information regarding the pathogencity of Cryptosporiopsis spp. (C. californiae, C. caliginosa and Cryptosporiopsis 
sp.) which have never been experimentally shown to be pathogens of Eucalyptus.

Acknowledgement We are grateful to many friends and colleagues associated with forestry companies in various parts of the world who have made it possible for us to collect specimens that made this study possible. The first author gratefully acknowledges Chiang Mai University Graduate School for partial support to this doctoral study.

Open Access This article is distributed under the terms of the Creative Commons Attribution Noncommercial License which permits any noncommercial use, distribution, and reproduction in any medium, provided the original author(s) and source are credited.

\section{References}

Barr ME (1978) The Diaporthales in North America with emphasis on Gnomonia and its segregates. Mycologia Memoir 7:1-232

Barr ME (1990) Prodromus to nonlichenised, pyrenomycetous members of class hymenoascomycetes. Mycotaxon 39:43-184

Castlebury LA, Rossman AY, Jaklitsch WJ, Vasilyeva LN (2002) A preliminary overview of the Diaporthales based on large subunit nuclear ribosomal DNA sequences. Mycologia 94:1017-1031

Cheewangkoon R, Crous PW, Hyde KD, Groenewald JZ, To-anan C (2008) Species of Mycosphaerella and related anamorphs on Eucalyptus leaves from Thailand. Persoonia 21:77-91

Cheewangkoon R, Groenewald JZ, Summerell BA, Hyde KD, Toanun C, Crous PW (2009) Myrtaceae, a cache of fungal biodiversity. Persoonia 23:55-85

Ciesla WM, Diekmann M, Putter CAJ (eds.) (1996) FAO/IPGRI Technical guidelines for the safe movement of germplasm, No. 17. Eucalyptus spp. FAO, IPGRI, ACIAR \& ASEAN, Rome, Italy

Crous PW (1998) Mycosphaerella spp. and their anamorphs associated with leaf spot diseases of Eucalyptus. Mycol Mem 21:1-170

Crous PW (2002) Taxonomy and pathology of Cylindrocladium (Calonectria) and allied genera. APS Press.

Crous PW (2009) Taxonomy and phylogeny of the genus Mycosphaerella and its anamorphs. Fungal Div 38:1-24

Crous PW, Wingfield MJ, Park RF (1991) Mycosphaerella nubilosa a synonym of M. molleriana. Mycol Res 95:628-632

Crous PW, Gams W, Stalpers JA, Robert V, Stegehuis G (2004a) MycoBank: an online initiative to launch mycology into the 21st century. Stud Mycol 50:19-22

Crous PW, Groenewald JZ, Risède J-M, Simoneau P, Hywel-Jones NL (2004b) Calonectria species and their Cylindrocladium anamorphs: species with sphaeropedunculate vesicles. Stud Mycol 50:415-430

Crous PW, Groenewald JZ, Risède JM, Simoneau P, Hyde KD (2006a) Calonectria species and their Cylindrocladium anamorphs: species with clavate vesicles. Stud Mycol 55:213-226

Crous PW, Slippers B, Wingfield MJ, Rheeder J, Marasas WFO, Philips AJL, Alves A, Burgess T, Barber P, Groenewald JZ (2006b) Phylogenetic lineages in the Botryosphaeriaceae. Stud Mycol 55:235-253

Crous PW, Verkley GJM, Groenewald JZ, Samson RA (eds.) (2009) Fungal biodiversity. CBS laboratory manual series. Centraalbureau voor Schimmelcultures, Utrecht, Netherlands
Edgerton CW (1908) Two little known Myxosporiums. Ann Mycol 6 (1):48-53

Ferreira FA, Silveira SF, Alfenas AC, Demuner AM (1998) Manchade-criptoriopsis em eucalipto no Brasil. Fitopatol Bras 23:414

Gadgil PD (2005) Fungi on trees and shrubs in New Zealand. Fungi of New Zealand volume 4. Fungal Divers Res Ser 16:1-437

Gadgil PD, Dick M (1999) Fungi Silvicolae Novazelandiae: 2. New Zeal J For Sci 29:440-458

Glass NL, Donaldson GC (1995) Development of primer sets designed for use with the PCR to amplify conserved genes from filamentous ascomycetes. Appl Environ Microbiol 61:1323-1330

Gryzenhout M, Myburg H, Wingfield BD, Wingfield MJ (2006) Cryphonectriaceae (Diaporthales), a new family including Cryphonectria, Chrysoporthe, Endothia and allied genera. Mycologia 98:239-249

de Hoog GS, Gerrits van den Ende AHG (1998) Molecular diagnostics of clinical strains of filamentous basidiomycetes. Mycoses 41:183-189

Lombard L, Rodas CA, Crous PW, Wingfield BD, Wingfield MJ (2009) Calonectria (Cylindrocladium) species associated with dying Pinus cuttings. Persoonia 23:41-47

Lombard L, Zhou XD, Crous PW, Wingfield BD, Wingfield MJ (2010) Calonectria species associated with cutting rot of Eucalyptus. Persoonia 24:1-11

Monod M (1983) Monographie taxonomique des Gnomoniaceae (del'ordre des Diaporthales). Beihefte zur Sydowia 9:1-315

van Niekerk JM, Groenewald JZ, Verkley GJM, Fourie PH, Wingfield MJ, Crous PW (2004) Systematic reappraisal of Coniella and Pilidiella, with specific reference to species occurring on Eucalyptus and Vitis in South Africa. Mycol Res 108:283-303

O'Donnell K, Cigelnik E (1997) Two divergent intragenomic rDNA ITS2 types within a monophyletic lineage of the fungus Fusarium are nonorthologous. Mol Phylogenet Evol 7:103-117

Old KM, Yuan ZQ (1994) Foliar and stem diseases of Eucalyptus in Vietnam and Thailand. Report of study visits. CSIRO Division of Forestry, Canberra

Old KM, Yuan ZQ (1999) Foliar and stem diseases of Eucalyptus in Vietnam and Thailand. Report prepared for CSIRO Division of Forestry and Australian Centre for International Agriculture Research, Canberra

Old KM, Dudzinski MJ, Pongpanich K, Yuan ZQ, Thu PQ, Nguyen NT (2002) Cryptosporiopsis leaf spot and shoot blight of eucalypts. Austral Plant Pathol 31:337-344

Old KM, Wingfield MJ, Yuan ZQ (2003) Cryptosporiopsis leaf blight. A manual of diseases of Eucalyptus in South-East Asia. CIFOR and ACIAR, Bogor, Indonesia, pp 10-13

Park RF, Keane PJ, Wingfield MJ, Crous PW (2000) Fungal diseases of eucalypt foliage. In: Keane PJ, Kile GA, Podger FD, Brown BN (eds) Diseases and pathogens of eucalypts. CSIRO publishing, Australia, pp 153-239

Rayner RW (1970) A mycological colour chart. CMI and British Mycological Society, Kew

Rehner SA, Samuels GJ (1994) Taxonomy and phylogeny of Gliocladium analysed from nuclear large subunit ribosomal DNA sequences. Mycol Res 98:625-634

Rossman AY, Farr DF, Castlebury LA (2007) A review of the phylogeny and biology of the Diaporthales. Mycoscience 48:135-144

Samuels GJ, Blackwell M (2001) Pyrenomycetes-fungi with perithecia. In: McLaughlin D, McLaughlin E (eds) The Mycota 
VII Part A. Systematics and evolution. Springer-Verlag, Berlin, pp 221-255

Sankaran KV, Sutton BC, Balasundaran M (1995) Cryptosporiopsis eucalypti sp.nov., causing leaf spots of eucalypts in Australia, India and U.S.A. Mycol Res 99:827-830

Sharma JK (1994) Pathological Investigation in Forest Nurseries and Plantations in Vietnam. Report of UNDP/FAO Project VIE/92/ 022, Hanoi

Sogonov MV, Castlebury LA, Rossman AY, Mejía LC, White JF (2008) Leaf-inhabiting genera of the Gnomoniaceae, Diaporthales. Stud Mycol 62:1-79

Sutton BC (1980) The coelomycetes. Fungi imperfecti with pycnidia, acervuli and stromata. Commonwealth Mycological Institute, Kew
Verkley GJM (1999) A monograph of the genus Pezicula and its anamorphs. Stud Mycol 44:1-180

Vilgalys R, Hester M (1990) Rapid genetic identification and mapping of enzymatically amplified ribosomal DNA from several Cryptococcus species. J Bacteriol 172:4238-4246

Voglmayr H, Jaklitsch WM (2008) Prosthecium species with Stegonsporium anamorphs on Acer. Mycol Res 112:885-905

Wehmeyer LE (1975) The pyrenomycetous fungi. Mycol Mem 6:1-250

White TJ, Bruns T, Lee J, Taylor J (1990) Amplification and direct sequencing of fungal ribosomal RNA genes for phylogenetics. In: Innis MA, Gelfand DH, Sninsky JJ, White TJ (eds) PCR protocols: a guide to methods and applications. Academic, San Diego, pp 315-322 